"Driving urban-rural migration through investment in water resource management in subsistence farming: the case of Machibini"

\begin{tabular}{|c|c|c|}
\hline AUTHORS & \multicolumn{2}{|l|}{$\begin{array}{l}\text { Olayemi Bakre } \\
\text { Nirmala Dorasamy }\end{array}$} \\
\hline ARTICLE INFO & \multicolumn{2}{|c|}{$\begin{array}{l}\text { Olayemi Bakre and Nirmala Dorasamy (2017). Driving urban-rural migration } \\
\text { through investment in water resource management in subsistence farming: the } \\
\text { case of Machibini. Environmental Economics, 8(1), 66-74. } \\
\text { doi:10.21511/ee.08(1).2017.07 }\end{array}$} \\
\hline DOI & \multicolumn{2}{|c|}{ http://dx.doi.org/10.21511/ee.08(1).2017.07 } \\
\hline RELEASED ON & \multicolumn{2}{|l|}{ Wednesday, 12 April 2017} \\
\hline & \multicolumn{2}{|l|}{$(\mathrm{cc}) \overline{\mathrm{BY}-\mathrm{NC}}$} \\
\hline LICENSE & \multicolumn{2}{|c|}{$\begin{array}{l}\text { This work is licensed under a Creative Commons Attribution-NonCommercial } 4.0 \\
\text { International License }\end{array}$} \\
\hline JOURNAL & \multicolumn{2}{|l|}{ "Environmental Economics" } \\
\hline ISSN PRINT & \multicolumn{2}{|l|}{$1998-6041$} \\
\hline ISSN ONLINE & \multicolumn{2}{|l|}{$1998-605 X$} \\
\hline PUBLISHER & \multicolumn{2}{|c|}{ LLC "Consulting Publishing Company "Business Perspectives" } \\
\hline FOUNDER & \multicolumn{2}{|c|}{ LLC "Consulting Publishing Company "Business Perspectives" } \\
\hline \multirow[b]{2}{*}{ NUMBER OF REFERENCES } & & ニシニ \\
\hline & NUMBER OF FIGURES & NUMBER OF TABLES \\
\hline 20 & 0 & 2 \\
\hline
\end{tabular}

C The author(s) 2023. This publication is an open access article. 


\title{
Driving urban-rural migration through investment in water resource management in subsistence farming: the case of Machibini
}

\begin{abstract}
The once thriving subsistence farming community of Machibini is currently defunct due to water shortages, inadequacy of governmental support and better livelihood in urban communities. This community alongside its neighbouring communities is characterized by poverty. A variety of strategies and initiatives has been initiated to address the cyclical poverty amongst these communities. This paucity has driven the youths to urban centres as a means of securing a better livelihood. More so, the constant ebb of mass rural-urban migration has created voluminous challenges.

As an agendum to creating a viable farming community in Machibini and "instigating an urban-rural migration", the paper recommends the reallocation of the surplus budgets of this community to the investment of water resource management as a strategy of transforming the subsistence into commercial farming, thereby creating employment opportunities for the unemployed rural, as well as urban dwellers, while reducing poverty to a reasonable extent.
\end{abstract}

Keywords: destruction of water resources, migration, investment, water resource management, subsistence farming, urban-rural migration, rural redress.

JEL Classification: Q54, Q57, Q12, Q25.

\section{Introduction}

Background: rural communities of Africa in the 60's. The livelihood and lifestyle of rural communities of Africa are quite synonymous. These similitudes could be found in aspects such as festivals, customs and farming practices, which are predominantly the subsistence mode of farming (Anthony et al., 2012; Nussbaum, 2003; Bigombe \& Khadiagala, 2004). Farming was the main source of livelihood amongst several rural communities of Africa in the 60's. Some of these communities, however, did not only produce for domestic consumptions, but also exported a surmountable quantity (Food and Agriculture Organization, 1960). Africa could conveniently feed itself in the 60's, while also exporting to Europe, North America and Asia. Unfortunately, the reverse is the case today, as enormous tonnage of food supplies is shipped into the African continent from other continents (Chauvin et al., 2012; USDA, 2015).

The discovery of crude oil in the mid-60's in countries such as Algeria, Angola, Democratic Republic of Congo (DRC) and Nigeria can partly be attributed to the shift from the agricultural sector to the oil and gas sector, as well as other nonagricultural sectors. The agricultural sector of these

(C) Olayemi Bakre, Nirmala Dorasamy, 2017.

Olayemi Bakre, Department of Public Management, Faculty of Management Sciences, Durban University of Technology, South Africa. Nirmala Dorasamy, Professor, Department of Public Management, Faculty of Management Sciences, Durban University of Technology, South Africa.

This is an Open Access article, distributed under the terms of the Creative Commons Attribution-NonCommercial 4.0 International license, which permits re-use, distribution, and reproduction, provided the materials aren't used for commercial purposes and the original work is properly cited. countries began to dwindle, as inadequate governmental support was given (Romanova, 2007; Odulari, 2008). Prior to this oil discovery in Nigeria, the groundnut pyramids and other agricultural produces contributed significantly to the Nigerian Gross Domestic Product (GDP) (Odulari, 2008; Uwakonye et al., 2006). More so, Egypt was known as the "power house of bailey", and was among the highest producers of bailey globally. Similar occurrences also took place in Algeria and Angola, which resulted in the neglect of the agricultural sector (Hamrick et al., 2014; Odulari, 2008; Uwakonye et al., 2006).

Furthermore, desertification and exhaustive exploitation of resources has been a challenge to the subsistence farming communities of Africa. Exemplifying with the case of Burkina Faso, where desertification has grossly consumed a sizeable portion of the previously arable farm lands, has resulted in significant portion of the rural populace leaving their traditional farming lifestyle for better livelihood in urban communities, while some other migrants had migrated to other African countries or overseas. It is forecasted that an estimated 60 million of inhabitants within the Sahel and Horn of Africa will migrate between 2016 and 2020 due to desertification (Pauleit, 2015; AfDB, OECD, UNDP, 2016). The migration pattern is projected to hit a vast population of Africa, particularly the rural communities, as desertification already affects twothirds of the African continent, and 65 per cent of its population (AfDB, OECD, UNDP 2016). The scenario in East Africa is synonymous with many other African rural communities, where the farmers no longer cultivate crops for a living, as was the dominant traditional practice a few decades ago. Environmental degradation due to climate change, 
changes in agricultural policies, and inability to compete with commercial farmers (by the subsistence farmers) have dissuaded many rural farmers who are often subsistence farmers (Bekker, 2006).

Similar to other rural communities of Africa, the South African traditional rural spaces have encountered several developmental challenges. Furthermore, the agrarian activities are gradually diminishing mainly due to water shortages; and while, gaining access to governmental grants has been problematic for a number of rural dwellers. Coupled with the rapid decline of agricultural employment, which is known to have previously provided employment opportunities for an estimated half of rural populace in some communities of South Africa, and while, in some other communities, an estimated one-third of the populace had benefited directly or indirectly from farming opportunities (Goldblatt, 2010; Quantec, 2013). All of these aforementioned lacunas have been some of the driving instigators of the rural-urban migration in South Africa (Barrios et al., 2006; Global Centre for Food Systems Innovation, 2014). More so, the inadequacy of infrastructure and service delivery backlogs, and limited non-agricultural opportunities have often driven the rural dwellers to either more congested rural communities with better employment opportunities or to urban centres. Such migration pattern is predominant amongst the Transkei and Ciskei in the Eastern Cape Province (Bekker, 2006).

Anthropological work on subsistence farming amongst East and Southern African rural communities is parallel to that of Machibini community. The previously thriving subsistence farming community of Machibini is situated in Mtubatuba Municipality, Northeastern axis of the KwaZulu-Natal Province, wherein more than 50 per cent of the working population benefited from farming activities. Many of the subsistence farmers of this community have abandoned their age-long inherited farm lands in search for greener opportunities in urban centres. This migration pattern is synonymous across rural communities of $\mathrm{KZN}$. This farming practice began to diminish in Machibini primarily due to water shortages alongside the challenges highlighted amongst the earlier mentioned rural communities. Thus, this has resulted in an unprecedented migration flow from Machibini to other communities with better livelihood opportunity in Mtubatuba, and cities or larger towns within the KwaZulu-Natal Province.

\section{Literature review}

1.1. Migration pattern between 1960 and 2015 . The year 2015 recorded the highest rate of migrant crisis since the 2nd World War. While some migrants had migrated for political reasons, some other migrants have migrated for economic reasons. The political instability in South Sudan has forced thousands of Sudanese to leave their home country for a safer neighboring country - Uganda. Such scenario is similar to that of Syria, where the political instability in the past five years has resulted in Syrians migrating to European countries. Contrary to their East African counterpart, majority of the West African citizenry such as Nigerians, Togolese, Ivorian's, Senegalese, as well as Southern African citizenry such as Zimbabweans, Mozambicans and Malawians have often migrated for economic reasons. The majority of these migrants have often migrated from their home country to the capital cities of their destinations, adding to population, and while, outstretching the limited facilities and infrastructure of such cities (Chen, 2014; Clark, 2009; Collier, 2016; Collier, 2013).

The unprecedented human mobility has brought about internal, as well as international movements across cities, resulting in overcongestion amongst some mega-cities across the globe. The UN DESA (2013) estimates the international migrants at 232 million, and while, the internal migrants at 740 million (UNDP, 2009). This report further alludes that an estimated 50 per cent of the international migrants reside in high income nations such as the US, Canada, Australia, Russia, United Arab Emirates, Saudi Arabia, United Kingdom, Spain, Germany and France. These migrants often reside in highly urbanized cities of these aforementioned countries (UN DESA, 2013).

It is forecasted that the majority of the world's population over the next 20-30 years will reside in highly urbanized cities of low and middle income countries, particularly Asian and African countries (UN DESA, 2013). In accordance with a report put forward by UN-Habitat (2013), Africa is ranked the second fastest urbanizing continent. Africa's urban population has grown geometrically between the 1960's and the present. In 1960, only one subSaharan African city (Johannesburg) had above one million inhabitants. By 1970, three other cities besides Johannesburg were having above one million inhabitants (Lagos, Kinshasa and Cape Town). By 2010, 33 African cities were having more than a million inhabitants (UN-Habitat, 2013). And by 2015, these population figures had increased significantly resulting in highly congested cities. The urban population of the Asian-Pacific region is estimated to rise to 63 per cent in the next few decades. This forecast is based upon the 120000 estimated migrants who are recorded to migrate to the Asian Pacific cities on a daily basis. These overwhelming flow of migrants have often surpassed 
the pace of infrastructural development of several middle and low income countries. The pace of urbanization in the Asian-Pacific region is beginning to mount pressure on governments of this region. Between 1990 and 2014, the population in this region increased by 1 billion inhabitants, which signifies more than 100 per cent population increment between 1950 and 1975; and also between 1975 and 2000, respectively. Similar population increases are further projected between 2000 and 2025 (UNESCAP, 2014 cited by IOM, 2015).

Furthermore, a report by the UN DESA (2014) forecasts high population growths among African and Asian cities in the course of the next two decades. This high population density is forecasted to take place amongst the cities of low and middle income countries. An estimated projection of 2.5 billion inhabitants is expected to be added to the current population of these African and Asian cities. As in 2014, over 54 per cent (3.9 billion) of the world population resided in urban centres. The trend of migration flows is evolving in consonance with the global economic situations. Regions such as the Western India, Brazil, East Asia and Southern Africa are fast attracting migrants due to their high economic growth. Invariably, several metros across the globe are consistently experiencing a constant ebb and flow of migrants between urban, regional, national and global communities, which has posed several adverse consequences. Hence, this calls for a political and strategic redress before such migrant flow becomes unbearable (International Organization for Migration (IOM), 2015).

\subsection{The South African migration pattern between}

1960 and 2015. Similarly to other countries, South Africa's internal migration is an under-researched subject matter. The inadequacy of research in this field does not necessarily imply its insignificance, but rather, the "historical absence of appropriate census data". The lack of appropriate census data prior to the 1996 Census impeded the accuracy of the internal migration records. The most reliable data back then was the 1996 census, which covered the years between 1975 and 1980. However, the weakness of this census was the exclusion of the former Venda, Bophuthatswana and Transkei homeland areas (Naidoo et al., 2009; Kok et al., 2003). In as much as accurate Census figures were not available, one clear assertion was that the rural populace over the years migrated en mass to urban communities. Anthropological studies in Southern African countries, South America and Asia are synonymous with the South African context, wherein the rural populace migrate to urban communities in search of better livelihood and opportunities.
According to the DPME (2015), there has been a gradual decline of rural populations as a percentage of total populations. The DPME (2015) further alleges that the South African rural population had dropped from 54 per cent in 1960 to 39 per cent in 2010. However, few other studies estimate the South African rural populace at 60 per cent in the 1960's (Christopher, 2011; Bureau of Statistics, 1968). More recent sources (Department of Rural Development and Land Reform, 2013: Trading Economics, 2016), however, estimate that 35.7 per cent to 37 per cent of the current South African populace reside in rural communities. As in 2001, the rural population was estimated at 43 per cent. According to Makgetla (2010), the population in the former homelands, which are predominantly the rural communities, grew by nine per cent between 1995 and 2008, while that of the metros grew by almost 40 per cent; secondary cities grew by 24 per cent; and while, the commercial farming communities grew by 15 per cent, which depicts an outward migration trend.

Between the 17th century and 1994, the apartheid government created a system, which sought to exploit the Black populace. The Blacks were compelled to work for the privileged White minority (mostly on commercial farms) (Feinstein, 2005 cited by (Camlinet al., 2014). As articulated by Camlin et al. (2014), the male migrants (from rural communities) were a "cornerstone of South Africa's segregationist economy". The apartheid government in a bid to extract cheap labor among the male (Black) migrants also imposed laws as a means to keep women in rural communities (Preston-Whyte, 1978). Despite the orchestrated tactic by the apartheid government in keeping the women in rural communities, quite opposite was the result, as the women folk also migrated independently between the late 19th century and early 20th century to urban communities. Majority of these migrants migrated to areas such as the Witwatersrand to secure a better livelihood, while benefiting from the "gold boom economy" (Bonner, 1990; van Onselen, 1982). While some of the women migrants served as domestic workers or were engaged in the informal sector, their male counterparts mostly worked in mines or on commercial farms (Camlin et al., 2014).

A divergent stream of indicators ranging from political to social and economic factors in the last two decades has influenced the causes, context, as well as the legislative controls of migration. The formal abolishment of the apartheid "influx control measures" in 1986 after a period the populace defied the laws and migrated to the cities in search of better livelihood instigated a consistent stream flow of 
migrants from the rural communities to urban centres (Todes, 1998). Hence, during this era, the rural migration was estimated to have increased from 2 per cent in 1980-1984 to 15.4 per cent in 1995-1999 per 1,000 population (Anderson, 2006 cited by Camlin et al., 2014).

More so, worth mentioning is the fact that women mostly migrated from one rural community of South Africa to the next, while their male counterparts often migrated from rural to urban communities. Furthermore, men were perceived to have migrated further distances, as they migrated within provinces, and went beyond the border in some instances (Camlin et al., 2014).

In summary, the current section shows the gradual decline in the rural population of South Africa which has no doubt consequently resulted in several adverse consequences on both rural and urban communities. The proceeding section highlights some of these adverse consequences.

1.3. Consequences of rural-urban migration. Varieties of studies conducted locally and internationally have enumerated the diverse impact on rural-urban migration on the host community, as well as rural communities (Mulcahy \& Kollamparambil, 2016; Greiner \& Sakdapolrak, 2013; Brauw et al., 2014; Albers et al., 2016; Siciliano, 2014). The current section of this paper highlights the several (adverse) consequences of this migration pattern on the South African urban communities, while arguing the need for a reversal of the high influx of rural-urban migrants. As elucidated by the UN DESA (2012), the urban communities of most low and middle income countries such as South Africa, where poverty and service delivery concerns still exist, will experience high rural-urban migration in the next two decades. The high influx of rural-urban migrants is set to result in congestion; outstretch the limited infrastructure, while also posing a threat to the environment (IOM, 2015). Policy makers have acknowledged these concern as a daunting task, as they find it problematic coping with the migration consequences (IOM, 2015). The UN-Habitat (2007) equally argues that this migration pattern can be attributed to the sporadic upsurge of slums in urban centres, which has become a common phenomenon in the Global South. These poorly managed informal settlements have often been characterized with poor sanitation alongside other vices (IOM, 2015). More so, the rural-urban migration can partly be attributed to the tussling of limited resources, amenities or opportunities in urban settings, which, in some cases, have resulted in violence. Such violent reaction is exemplified by the 2008 and 2015 South African xenophobia crisis in the cities of Johannesburg and Durban (IOB, 2015).

Furthermore, the high congestion of urban centres due to the rural-urban migration adversely impacts on environment. The high environmental risks have posed a developmental concern to highly populated urban communities. Such underestimated environmental risk factors such as poor sanitation, unsafe water and air pollution led to staggering 246000 premature deaths (UN-Habitat, 2008). Experts on climate change have also alluded that the high congestion in urban cities of Africa has multi-faceted consequences on the climate change. Based on the current trend, it is forecasted that the African temperature will increase from 1.5 to $3^{\circ} \mathrm{C}$ by the year 2015 . And should this trend continue unmitigated, the heightened heat will exacerbate the poverty level amongst African countries, while magnifying the challenges attributed to the urban ecosystem (Burke, Hsiang, and Miguel, 2015). Studies conducted by the AfDB, OECD and UNDP (2015) do mention that the climate change concern has been responsible for the heavier rainfall in the Eastern African region and is the cause of the current wildfires, drought, extreme heat and dryness experienced across some provinces of South Africa. This has not only impacted on humans, but also on the modification of physical and chemical properties of the atmosphere; soil surfaces, vegetation and animals as well. Furthermore, amongst the major consequences of the rural-urban migration are the breaking of family and cultural bond in rural areas; increases in the prices of commodities, housing and transport in urban centres (Collier, 2016; Camlin et al., 2014).

The gravity of these aforementioned consequences of the rural-urban migration might have been reduced to a reasonable extent, but due to the inefficient management of land and water resources amongst rural communities of South Africa alongside the inappropriate land tenure systems, has undermined the possibility of a progressive and sustainable investment in rural communities (Global Centre for Food Systems Innovation, 2014).

The aforecited consequences are synonymous to the community of Machibini, and surrounding communities such as Msane, Khula Village, Ndombeni and Madwaleni. Thus, the imperativeness of reversing this migration trend through the creation of viable rural spaces through the investment of water resources management (WRM) cannot be over-emphasized. 


\section{Aim}

The core objective of this paper is to explore pragmatic strategies through which subsistence farming in rural communities of South Africa can be revamped.

Furthermore, the following objectives will be addressed:

- strategies to reverse the rural-urban migration pattern in South Africa;

- exploring the possible impacts of investment on WRM in subsistence farming.

\section{Methodology}

To achieve the study's objectives, both elements of quantitative (questionnaires) and qualitative (interviews) were utilized to obtain pertinent facts. Questionnaires were administered to 91 subsistence farmers in Machibini and surrounding farming settlements. However, only 73 of these subsistence farmers completed the questionnaires. Each of these questionnaires was translated into IsiZulu, as Zulu was the predominant mode of communication amongst these farmers. Structured interviews were conducted amongst 8 Agricultural Extension workers and 2 key personnel at the Department of Agriculture, Environmental Affairs and Rural Development (Mtubatuba). The quantitative sample population was chosen through a purposive non-probability sampling method, while the qualitative sample population was selected through judgmental non-probability sampling method. The line of questioning centred around reasons for the high flow of rural-urban migration in the community; challenges of subsistence farming; and while, exploring the current interventions this community uses to mitigate challenges attributed to subsistence farming.

\section{Reversing the trend through investment in WRM}

The key feature of this paper is to contribute to the on-going discuss regarding the unprecedented flow of migrants to urban centres. To mitigate this lacuna, a pathway could be investing in WRM. Several opportunities to improve household income and food security are missed due to poor and unsustainable water usage (Calzadilla et al., 2013). Calzadilla et al. (2013) further state that a diverse array of potentials can be tapped into through the utilization of WRM strategies for agricultural proposes. Mati (2007) collaborates this assertion when he mentions that several opportunities are lost through the non-utilization of green water recapitalization. He further makes an argument using a 38 million ha of land. Within this 38 million ha of land, WRM is only being practised on 3 million ha of land, wherein the regions' (estimated) full potential is at 18 million ha. These land portions are situated within the East and Southern African regions, which would have been beneficial to a wide majority of rural poor farmers if judiciously used.

Mati (2007) affirms that a significant portion of East and Southern African farmers are conversant with water management technologies and approaches, however, these experiences, technicalities and competencies are unevenly spread across different farming communities, while some other cutting edge water resource management techniques are confined to publications. Thus, this calls for the cross-fertilization of skills, knowledge and information amongst farmers, extension workers, researchers, governmental entities and other stake holders. Ironically, the most densely populated regions across the globe are often the most water scarce regions (Falkenmark, 2013). Hence, it becomes imperative to maximize every single drop of water through the WRM intervention.

To achieve a successful WRM in a subsistence farming community such as the Machibini, it is essential for stakeholders to work collectively and in the same direction. The input of the local councillor, policy makers, engineers, researchers, water management experts and non-governmental entities are imperative, while not only involving agricultural extension workers and subsistence farmers of this locality, but also allowing them (Agricultural Extension workers and subsistence farmers) to take ownership of this initiative.

Table 1. On-going subsistence farming projects in Machibini and environ (Mtubatuba Municipality)

\begin{tabular}{|l|c|c|c|c|c|}
\hline \multicolumn{1}{|c|}{ Ward } & Ward 1 & Ward 3 & Ward 7 & Ward 12 & Ward 19 \\
\hline Location & Msane & Khula village & Ndombeni & Madwaleni & Machibini \\
\hline Extension worker & Hlungiwe Gumede & Mrs. ZP Mthemba & Snenhlanhla Msweli & Mr Mzothule Buthelezi & Mrs Mbatha \\
\hline Project name & Simunye & kkusasalethu & Siyathuthuka project & Madwaleni & Isukamuva project \\
\hline Duration of project & Four years & Six years & Three years & Seven years & Four years \\
\hline Size of farm & Ihectare & 2 hectares & 2 hectares & 4 hectares & 1 hectare \\
\hline Number of farmers & 20 & 35 & 6 & 35 & 30 \\
\hline Crops grown & $\begin{array}{c}\text { Maize, spinach, beans an } \\
\text { carrot }\end{array}$ & Maize and lettuce & $\begin{array}{c}\text { Maize, spinach, beans and } \\
\text { carrot }\end{array}$ & $\begin{array}{c}\text { Sugarcane, maize, spinach, } \\
\text { cabbage, carrot, lettuce, tomato }\end{array}$ & $\begin{array}{c}\text { Maize, spinach, beans and } \\
\text { carrot }\end{array}$ \\
\hline Water source & Only rainfall (54 $\mathrm{mm}$ ) & Only rainfall (52 $\mathrm{mm}$ ) & Only rainfall (56 mm) & Only rainfall (54 mm) & Only rainfall (52 mm) \\
\hline Major challenges & $\begin{array}{c}\text { Water scarcity, animal } \\
\text { trampling }\end{array}$ & Water shortage & $\begin{array}{c}\text { Water scarcity, no fencing an } \\
\text { insect attack }\end{array}$ & Water shortage & Water shortage \\
\hline
\end{tabular}


Table 1 provides a synopsis of the on-going subsistence farming projects in Machibini and surrounding. A concurrent issue all these projects have is "water scarcity". As emphasized by the Extension workers of this locality, addressing the water scarcity constraint may open up vast opportunities and potentials for the subsistence farmers, as well as these farming communities.

Investment in WRM in the above communities is long overdue, as water scarcity has been a major impediment constraining the growth of some of the projects, which had been running for as long as 3035 years. When further probed as to how they had been sustaining their projects over the years, the majority of these farmers attested that they often use rain water harvesting, while some who have their projects in close proximity to a nearby river pump water from rivers, while some rely on water shed management; soil and water conservation and soil fertility, respectively. However, the farmers further explained that rain water harvesting approach is only feasible during the rainy summer period, which is often between November and March. Thus, during other months of the year, they experience difficulties in sustaining their farming projects.

Oftentimes, the initiation and sustainability of cutting edge water management projects are usually expensive. Their cost intensity is often dependent on their level of sophistication, size of farm land, type of crop to be cultivated, topography, soil type, rainfall pattern, topography and humidity (Mulat, 2013, pp. 3-5 cited by Bakre, 2015). Investing in WRM in the Machibini community of Mtubatuba Municipality is worthwhile, as this municipality's budget had been in surplus since 2011. This budget surplus is depicted in Table 2 .

Table 2. Forecast of revenue and expenditure of Mtubatuba Municipality between 2011 and 2018

\begin{tabular}{|c|c|c|c|c|}
\hline $\mathrm{s} / \mathrm{n}$ & Year & Revenue & Expenditure & Surplus \\
\hline 1 & $2011 / 12$ & 79,696 & 21,757 & 57,939 \\
\hline 2 & $2012 / 13$ & 92,526 & 20,804 & 71,722 \\
\hline 3 & $2013 / 14$ & 103,121 & 29,361 & 76,190 \\
\hline 4 & $2014 / 15$ & 127,347 & 22,954 & 104,393 \\
\hline 5 & $2015 / 16$ & 162,407 & 25,215 & 137,192 \\
\hline 6 & $2016 / 17$ & 171,668 & 26,499 & 145,169 \\
\hline 7 & $2017 / 18$ & 174,123 & 27,837 & 146,286 \\
\hline
\end{tabular}

Source: adapted from Mtubatuba Municipality Draft Budget and MTREF (2014, pp. 7-14).

As indicated in Table 2, since 2011, the Mtubatuba Municipality in which Machibini is situated had recorded an excess in its budget since 2011. Hence, such yearly surpluses could be invested in WRM.

Should such investment be made, it is anticipated that it will have a multi-faceted impact on the subsistence farmers, community, as well as the municipality. The expansion of the aforementioned farming projects can be gradually developed similar to that of the water scarce farming lands in Israel, which were developed through several years of policy assertiveness, political will and research (Mitrani and Blaustein, 2008). Should South Africa adopt suitable water management techniques used by the Israeli, it could possibly transform the ruralurban migration into urban-rural migration, while accelerating rural development and curbing poverty to a reasonable extent among the populace of Machibini and surrounding. Through a successful water management strategy in Machibini, the ongoing farming projects can be turned into large scale commercialized farms. Such initiative in the long run can be orchestrated to attract the unemployed in urban communities, induce inter and intra provincial export of farm goods, while also creating employment opportunities for the rural populace.

\section{Diversifying the South African economy through viable rural spaces}

Governments across the globe need to start thinking in a different and more pragmatic direction. One of such insightful and pragmatic directions could be the creation of viable rural spaces as an agendum to diversify the economy, while equally creating employment opportunities for their citizenry.

The imperativeness of diversifying the South African economy through viable rural spaces cannot be overemphasized in a country, where a significant portion of its populace lives below the poverty line (Ginneken et al., 2010). More so, the trio-challenges of marginalization, inequality and poverty, which are partly attributed to high incidences of unemployment, point to the need to create viable rural spaces. As in the third quarter of 2016, 26.7 per cent of able-bodied South Africans were unemployed (Statistics South Africa, 2016). Thus, an in-depth structuring aimed at reinvigorating subsistence farming through WRM in Machibini can possibly reduce unemployment, while also addressing these trio-challenges.

Furthermore, empirical studies have shown that countries that focus on rural communities often are able to tackle poverty faster than governments who focus mainly on urban communities or the middle class (http://www.polity.org.za/polity/govdocs /rdp/rural2.html cited by Bakre, 2015).

Orchestrating a viable rural space not only requires the working together of rural developmental stakeholders, but also requires the training of individuals on water management, as South Africa has only few experts in this field. Thus, the training of more people to fill this 
gap becomes imperative in creating viable rural spaces through WRM (Department of Water Affairs, 2012). More importantly, to drive this initiative, tailor made policies on WRM should be incorporated into the Integrated Development Plan (IDP).

Phuhlisani Solutions (2009), however, argues that a critical challenge attributed to the workability of creating viable rural spaces lies in the inadequacy of human capacity among rural municipal employees. To address this, the involvement of the private sector can be used to tackle this incompetence. The involvement of the private sector can open up a new array of opportunities. The involvement and investment coming from the private sector can drive the predominant subsistence farming practices in rural communities of KwaZulu-Natal, Mpumalanga, Limpopo and Eastern Cape into commercial farming. Studies have shown that several untapped developmental enterprising opportunities exist within the rural farming communities of KwaZulu-Natal (South Africa, 2012b). Again, the expertise and resources of the private sector can be used in reinvigorating the weak rural municipal structures. This may come through the outsourcing of operational and maintenance obligations as a means to sustain WRM in the short, medium and long term.

Revamping the decaying subsistence farming community of Machibini and surrounding subsistence farming communities through tailor-made WRM techniques can possibly create an avenue for exportation of agricultural produces. South Africa alongside other Southern African nations had been importing surmountable tonnages of agricultural produces from Indonesia, India, Thailand and Malaysia in the last five to ten years, which accounts for an estimated 30 per cent of all agricultural produces into the Southern African region (USDA, 2015). Amongst South Africa's top agricultural products imported are sugar, vegetables and poultry (USDA, 2015). However, these agricultural produces can possibly be produced in commercial (export) quantity, while also satisfying the local populace. KwaZulu-Natal, for instance, has the potential to produce sugar, vegetables and poultry at commercial (export) quantity, while also exporting to Southern African countries and Asia. However, inadequacy of attention to the agricultural sector, poor WRM competence, lack of political will, amongst other factors, have made it almost impossible for the KwaZulu-Natal Province to be a major exporter of agricultural produces. Thus, loss of opportunities amongst the rural farming communities (Garikai, 2014; Goldblatt, 2010).

As noted at the inception of this paper, an estimated 60 per cent of the South African populace resided in the rural communities in the 60 's, while the rest of the populace resided in urban centres. About fifty years on, the rural-urban populace had shown a reversal. In as much as it is far beyond reason to drive 60 per cent of the South African populace to rural communities at present, the paper attempts to initiate viable rural spaces with the intent of keeping the rural populace in their communities, while also driving the urban populace to rural communities through captivating opportunities.

\section{Conclusions}

The pace of rural-urban migration is fast outpacing the developmental growth in most cities of low and middle-income countries. This unprecedented migration trend has resulted in numerous and overwhelming challenges in urban centres, which are inclusive of outstretch of urban infrastructure, high unemployment, high crime rate, spread of slums in cities xenophobic attacks and protests. To address this concern, the paper recommends the creation of viable rural communities in South Africa through the investment of WRM as an agendum to transforming the "rural-urban" migration into an "urban-rural" migration. Having identified the agricultural potentials of most rural communities of South Africa, particularly within the KwaZulu-Natal and Eastern Cape Provinces, these communities could no doubt create employment, reduce the rural-urban migration and most importantly, take several million of individuals out of the poverty stricken circle. However, this agricultural potential has been undermined by water scarcity. This research, thus, advocates an interactive participation amongst stakeholders to formulate, design and invest in WRM for agricultural purposes in rural communities as an agendum to create viable rural communities. Having identified a previously thriving subsistence farming community in Machibini, in the Mtubatuba Municipality, this suggested thar rural developmental intervention can be pilot tested herein before cascading to neighboring rural communities within this Municipality. The creation of viable rural spaces may be the future growth path for low income and middle income countries across Africa, as this is projected to diversify growth, accelerate rural development, while bridging the inequality gap. More so, the practicability of this rural developmental intervention requires new line of thinking amongst grassroots politicians alongside stakeholders. Additionally, it is imperative to educate the community of Machibini on climate change concerns, as a vast majority of the participants of the study attributed water scarcity as a form of punishment from their gods and ancestors due to the communal wrong doings. Lastly, this paper presents a diverse array of opportunities for further researches, one of which is "soil conservative management", as soil plays an intricate role in sustainable farming and rural development. 


\section{References}

1. AfBD/OECD/UNDP. (2015). African Economic Outlook 2015: Sustainable cities and structural transformation, OECD Publishing, Paris. Available at: http://dx.doi.org/10.1787/aeo-2015-en. Accessed on 14 August 2016.

2. Agergaard, J., Fold, N. \& Gough, K. (eds.). (2010). Rural-Urban Dynamics: Livelihoods, mobility and markets in African and Asian Frontiers, Routledge, Abingdon, Oxon, UK.

3. Anthony, D., Baggott, R., Tanner, J., Jones, K., Evans., H., Perkins, G. \& Palmer, H. (2012). Health, lifestyle, belief and knowledge differences between two ethnic groups with specific reference to tobacco, diet and physical activity, Journal of Advanced Nursing, 68(11), pp. 2496-2503. doi: 10.1111/j.1365-2648.2012.05948.x.

4. Bakre, R.O. (2015). Water resource management for subsistence farming in ward 19 of KwaZulu-Natal. M.Tech, Durban University of Technology. Available at: http://ir.dut.ac.za/bitstream/handle/ 10321/1305/BAKRE_2015.pdf?sequence=1\&isAllowed=y. Accessed on 11 August 2016.

5. Barrios, S., Bertinelli, L. \& Strobl, E. (2006). Climatic change and rural-urban migration: The case of sub-saharan Africa, Core Discussion Paper No. 2006/46. Available at: http://papers.ssrn.com/sol3/papers.cfm? abstract_id=925652\&download=yes (Accessed 19 May 2016).

6. Bekker, S. (2006). Migration from South Africa's rural sending areas: changing intentions and changing destinations. Available at: www.simonbekker.com/.../Scalabrini\%20paper\%20internal\%20migration. Accessed on 6 April 2016.

7. Bhatti, A., Koike, T. \& Nasu, S. (2012). Water resources management: pathways for sustainable economic growth and poverty eradication. Available at: http://management.koch-itech.ac.jp/ssms_papers/sms125687_fd05c295e09d9310bc02c5ae26225212.pdf. Accessed on 6 August 2016.

8. Bigombe, B. \& Khadiagala, G.M. (2004). Major trends affecting families in sub-saharan Africa (online). Available at: http://www.un.org/esa/socdev/family/Publications/mtbigombe.pdf. . Accessed on 23 May 2016.

9. Calzadilla, A., Zhu, T., Rehdanz, K., Tol, R.S.J. \& Ringler, C. (2013). Economy wide impacts of climate change on agriculture in Sub-Saharan Africa, Ecological Economics, 93, pp. 150-165.

10. Camlin, C.S., Snow, R.C. \& Hosegood, V. (2014). Gendered Patterns of Migration in Rural South Africa. Popul. Space Place, 20, pp. 528-551. Available at: http://onlinelibrary.wiley.com/doi/10.1002/psp.1794/pdf. Accessed on 28 September 2016.

11. Chauvin, D.N., Mulangu, F. \& Porto, G. (2012). Food Production and Consumption Trends in Sub-Saharan Africa: Prospects for the Transformation of the Agricultural Sector. United Nations Development Programme. Available at: http://www.fao.org/docrep/ /016/ap648e/ap648e.pdf. Accessed on 11 May 2016.

12. Chen, M. et al. (2014). The global pattern of urbanization and economic growth: Evidence from the last three decades, PLOS One, 9:8, e103799. Available at: http://doi.org/10.1371/journal.pone.0103799. Accessed on 11 May 2016.

13. Christopher, A.J. (2011). The Union of South Africa censuses 1911-1960: an incomplete record, 56(2). Available at: http://www.scielo.org.za/pdf/hist/v56n2/v56n2a01.pdf. Accessed on 12 May 2016.

14. Clark, P. (2009). European Cities and Towns 400-2000, Oxford University Press, Oxford, UK.

15. Collier, P. (2013). Building African cities that work, paper prepared for the Centre for Development and Enterprise, commissioned for Cities of Hope project.

16. Collier, P. (2016). African urbanization: An analytic policy guide, International Growth Centre. Available at: www.theigc.org/wp-content/uploads/2016/01/African-UrbanizationJan2016_Collier_Formatted-1.pdf. Accessed on 5 May 2016.

17. Daniels, R.C., Partridge, A., Kekana, D. \& Musundwa, S. (2013). Rural Livelihoods in South Africa. Cape Town: SALDRU, University of Cape Town. SALDRU Working Paper Number 122/ NIDS Discussion Paper 2013/4.

18. Falkenmark, M. (2013). Growing water scarcity in agriculture: future challenge to global water security. Available at: http://rsta.royalsocietypublishing.org/content/371/2002/20120410. Short. Accessed on 8 May 2016.

19. Fischer, R. (2009). Rural-Urban Migration. A necessity to survive, Munich, GRIN Verlag. Available at: http://www.grin.com/en/e-book/180759/rural-urban-migration-a-necessity-to-survive. Accessed on 16 September 2016.

20. Food and Agriculture Organization of the United Nations. (1960). The state of food and agriculture 1960. Documentation prepared for the Center on land problems in Asia and the Far East, held in Bangkok, Thailand, 22 November II December 1954, under the FAO Expanded Technical Assistance Program. ROIDC, 1955. Rome.

21. Garikai, M. (2014). Assessment of vegetable postharvest losses among smallholder farmers in Umbumbulu area of Kwazulu-Natal Province, South Africa. Masters Dissertation, University of KwaZulu-Natal. Available at: https://researchspace.ukzn.ac.za/bitstream/handle/10413/11918/Garikai_Maremera_2014.pdf?sequence=1\&is Allowed=y. Accessed on 30 June 2016.

22. Ginneken, N., Lewin, S \& Berridge, V. (2010). The Emergence of community health worker programmes in the late apartheid era in South Africa: An historical analyzis, Social Science and Medicine, 71, pp. 1110-1118 (online). Available at: www.elsevier.com/locate/socscimed. Accessed on 2 April 2016.

23. Global Centre for Food Systems Innovation. (2014). Population Growth, Climate Change and Pressure on the Land - Eastern and Southern Africa, Michigan State University. 
24. Goldblatt, A. (2010). Agriculture: facts and trends in South Africa. Available at: http://awsassets.wwf.org.za/downloads/facts_brochure_mockup_04_b.pdf. Accessed on 13 May 2016.

25. Hamrick, D., Ahmed, G., Guinn, A., Abdulsamad, A., Goger, A., Daly, J., Morgan, J. \& Gereffi, G. (2014). Comparing Egypt and Saudi Arabia's Wheat GVC Duke University, 2. Available at: https://sites.duke.edu/minerva/files/2013/08/4-2014_CGGC_Research-Brief_-Egypt-and-KSA-Wheat-GVC.pdf. Accessed on 21 May 2016.

26. Kok, P., Donovan, M., Bouare., O. \& Van Zyl, J. (2003). Post-Apartheid patterns of internal migration in South Africa. Available at: $\quad$ https://books.google.co.za/books?hl=en\&1r=\&id=N_ntHrjledIC\&oi=fnd\&p $\mathrm{g}=\mathrm{PR} 7 \& \mathrm{dq}=$ migration+in+south+africa\&ots=IqnxMAG7kB\&sig=sBqtCweWSAqthScqCjEMvNnHAQM\#v=one page\&q=migration\%20in\%20south\%20africa\&f=false. Accessed on 12 September 2016.

27. Makgetla, N.S. (2010). Synthesis Paper. Conference on rural development, Delhi, India, April. Development Bank South Africa.

28. Mitrani, T.A. \& Blaustein, J. (2008). Government focal point. Institute for desert research, Ben Gurion University, Chairman of Land Development Committee, Jewish National Fund (JNF), Israel.

29. Mulcahy, K. \& Kollamparambil, U. (2016). The Impact of Rural-Urban Migration on Subjective Well-Being in South Africa, Journal of developmental studies, 52(9), pp. 1357-1371. Available at: http://www.tandfonline.com/doi/abs/10.1080/00220388.2016.1171844. Accessed of 3 September 2016.

30. Nussbaum, B. (2003). African Culture and Ubuntu Reflections of a South African in America, World Business Academy, 17(1). Available at: http://www.barbaranussbaum.com/downloads/perspectives.pdf. Accessed on 16 May 2016.

31. Odulari, G.O. (2008). Crude oil and the Nigerian economic performance, Oil and gas business. Available at: http://www.ogbus.ru/eng. Accessed on 13 June 2016.

32. Phuhlisani Solutions. (2009). International and local approaches to rural development, Key issues and questions: A review of the literature for the Drakenstein Municipality. Available at: http://www.phuhlisani.com/oid\%5 Cdownloads\%5C26082009\%20RD\%20literature\%20review\%2001.pdf . Accessed on 20 May 2016.

33. Quantec. (2013). RSA Standardised Industry. Available at: http://quanis1.easydata.co.za/. Accessed on 4 June, 2016. Quantec Research (Pty) Ltd., Pretoria, RSA.

34. Republic of South Africa. Department of Water Affairs. (2012). National Water Resource Strategy 2, Government Printer.

35. Republic of South Africa. (2012). Implementation of the rural development programme and its implications for the intergovernmental fiscal relations system in South Africa. Available at: http://www.ffc.co.za/.../submissions/.../Financial\%20and\%20Fiscal\%20Commission\%20201/ Accessed on 11 April 2016.

36. Romanova, I. (2007). Oil boom in Nigeria and its consequences for the country s economic development. Available at: http://www.grin.com/en/e-book/67959/oil-boom-in-nigeria-and-its-consequences-for-the-country\% E2\%80\%99s-economic-development. Accessed on 12 June 2016.

37. South Africa. Bureau of Statistics. (1968). Urban and rural population of South Africa 1904 to 1960, Government Printer.

38. South Africa. Department of Rural Development and Land Reform. (2013). Implementation Evaluation of the Comprehensive Rural Development Programme (CRDP): Final Full Report, Government Printer. Pretoria.

39. Statistics South Africa. (2012). Census 2011.

40. Statistics South Africa. (2012b). General Household Survey.

41. Statistics South Africa. (2016). Yearly Archives: 2016. Available at: http://www.statssa.gov.za/?m=2016. Accessed on 12 November 2016.

42. Trading Economics. (2016). Rural population (\% of total population) in South Africa(Online). Available at: http://www.tradingeconomics.com/south-africa/rural-population-percent-of-total-population-wb-data.html. Accessed on 21 July 2016.

43. World Bank. (2011). World Development Indicators. Available at: http://data.worldbank.org/indicator. Accessed on 19 October 2016.

44. The Presidency. (2015). Background paper: Rural transformationTwenty Year Review: South Africa 1994-2014, Department of Planning, Monitoring and Evaluation. Available at: http://www.dpme.gov.za/ .../20\%20Years\%20Review/20\%20Year\%20Review\%20Document. Accessed on 15 August 2016.

45. United Nations Human Settlements Programme (UN-Habitat). (2013). State of the World's Cities 2012/2013 Prosperity of Cities. Routledge, New York. Available at: http://unhabitat.org/books/prosperity-ofcities-state-ofthe-worlds-cities-20122013. Accessed on 22 August 2016.

46. United States Department of Agriculture. (2015). International Agricultural Trade Report. Available at: https://www.fas.usda.gov/sites/default/files/2015-11/11-2015_sub\%20-saharan_africa_iatr_0.pdf. Accessed on 11 April 2016.

47. Uwakonye, M.N., Osho, G.S. \& Anucha, H. (2006). The Impact of oil and gas production on the Nigerian economy: A Rural Sector Econometric Model, International Business and Economics Research Journal, 5(2), pp. 61-76. 